\title{
The effect of trace mineral source and concentration on ruminal digestion and mineral solubility
}

\author{
O. N. Genther and S. L. Hansen ${ }^{1}$ \\ Department of Animal Science, lowa State University, Ames 50011
}

\begin{abstract}
The objective of this experiment was to compare the effect of sources of sulfate trace mineral (STM) and hydroxy trace mineral (HTM) at different inclusions on digestibility of dry matter (DM) and neutral detergent fiber and solubility of $\mathrm{Cu}, \mathrm{Mn}$, and $\mathrm{Zn}$ in the rumen and abomasum of cattle. Five ruminally cannulated steers were used in a $5 \times 5$ Latin square design and individually fed a corn silage-based diet on an ad libitum basis. The 5 dietary treatments were as follows: control: no supplemental $\mathrm{Cu}, \mathrm{Mn}$, or $\mathrm{Zn}$, analyzed to contain $7.4 \mathrm{mg}$ of $\mathrm{Cu}, 30.8 \mathrm{mg}$ of $\mathrm{Mn}$, and $32.1 \mathrm{mg}$ of $\mathrm{Zn}$ per kilogram of diet DM (CON); low sulfate: $5 \mathrm{mg}$ of $\mathrm{Cu} / \mathrm{kg}$ of $\mathrm{DM}$ supplemented from $\mathrm{CuSO}_{4}, 15$ $\mathrm{mg}$ of $\mathrm{Mn} / \mathrm{kg}$ of $\mathrm{DM}$ from $\mathrm{MnSO}_{4}$, and $30 \mathrm{mg}$ of $\mathrm{Zn} /$ $\mathrm{kg}$ of $\mathrm{DM}$ from $\mathrm{ZnSO}_{4}$; low HTM: $5 \mathrm{mg}$ of $\mathrm{Cu} / \mathrm{kg}$ of DM supplemented from basic copper chloride (IntelliBond C; Micronutrients Inc., Indianapolis, IN), 15 $\mathrm{mg}$ of $\mathrm{Mn} / \mathrm{kg}$ of DM from manganese hydroxychloride (IntelliBond M; Micronutrients Inc.), and $30 \mathrm{mg}$ of Zn/ $\mathrm{kg}$ of DM from zinc hydroxychloride (IntelliBond Z; Micronutrients Inc.); high sulfate: $25 \mathrm{mg}$ of $\mathrm{Cu} / \mathrm{kg}$ of DM supplemented from $\mathrm{CuSO}_{4}, 60 \mathrm{mg}$ of $\mathrm{Mn} / \mathrm{kg}$ of DM from $\mathrm{MnSO}_{4}$, and $120 \mathrm{mg}$ of $\mathrm{Zn} / \mathrm{kg}$ of $\mathrm{DM}$ from $\mathrm{ZnSO}_{4}$; and high HTM: $25 \mathrm{mg}$ of $\mathrm{Cu} / \mathrm{kg}$ of DM supplemented from basic copper chloride, $60 \mathrm{mg}$ of $\mathrm{Mn} / \mathrm{kg}$ of $\mathrm{DM}$ from manganese hydroxychloride, and $120 \mathrm{mg}$ of $\mathrm{Zn} / \mathrm{kg}$ of DM from zinc hydroxychloride. Periods lasted for 12 d, with $10 \mathrm{~d}$ of diet adaptation. Dacron bags containing the CON total mixed ration were inserted on $\mathrm{d} 11$ at $0 \mathrm{~h}$ and were removed at $6,12,24$, and $36 \mathrm{~h}$ after insertion. Dry matter and neutral detergent fiber disappearances and rumen and simulated abomasal trace mineral solubilities were evaluated. Dietary treatment did not affect DM intake. Dry matter disappearance was lesser in supplemental TM treatments and greater in CON than the STM treatments, although the CON and HTM treatments did not differ. Neutral detergent fiber disappearance was not affected by treatment. $\mathrm{Ru}-$
\end{abstract}

Received July 15, 2014.

Accepted September 30, 2014.

${ }^{1}$ Corresponding author: slhansen@iastate.edu minally soluble $\mathrm{Cu}$ and $\mathrm{Mn}$ concentrations were least in $\mathrm{CON}$ and were lesser in HTM-containing treatments compared with STM treatments. However, in the abomasum, solubilities of $\mathrm{Cu}$ and $\mathrm{Mn}$ were similar across trace mineral sources. Ruminal and simulated abomasal soluble Zn was greater in the HTM treatments than in CON and STM, driven by the greater solubility of the high HTM treatment. Under the conditions of this study, supplementing trace minerals as STM decreased DM digestibility, whereas HTM did not affect DM digestibility. Additionally, $\mathrm{Cu}$ and $\mathrm{Mn}$ from HTM sources were relatively insoluble in the rumen but had similar solubility as STM at the $\mathrm{pH}$ found in the abomasum, suggesting that these minerals should be available for absorption in the intestine.

Key words: ruminant, trace mineral, neutral detergent fiber

\section{INTRODUCTION}

Rumen microorganisms require trace minerals (TM) for proper function. However, most research has shown that microorganism requirements for $\mathrm{Cu}, \mathrm{Mn}$, and $\mathrm{Zn}$ are minimal, much less than those typically provided by ruminant diets (Hubbert et al., 1958; Martinez and Church, 1970). Dietary concentrations of TM well beyond NRC (2000) recommendations are commonly fed in the feedlot industry (Vasconcelos and Galyean, 2007), whereas TM supplementation in the dairy industry remains uncharacterized. In vitro data also suggest that relatively small concentrations of $\mathrm{Cu}, \mathrm{Mn}$, and Zn can negatively affect cellulose digestion, whereas in vivo experimental results have been less consistent. Supplementation of $\mathrm{Cu}(20 \mathrm{mg}$ of $\mathrm{Cu} / \mathrm{kg}$ of diet DM) had a negative effect on finishing-cattle gain and feed efficiency (Engle and Spears, 2000a); however, the addition of similar concentrations in another study had no effect on rumen fermentation (Engle and Spears, $2000 \mathrm{~b})$. In vivo studies also suggest that a diet that is deficient in $\mathrm{Zn}$ for the animal is adequate for rumen microorganisms, although excessive dietary Zn concentrations may lessen DM digestibility (Somers and Underwood, 1969; Arelovich et al., 2000). Overall, this presents a challenge to balance TM supplementation to 
meet animal needs while avoiding negative effects on ruminal activity.

Trace mineral solubility can greatly affect the total concentration that is available to rumen microbes because only soluble minerals are available for use or interactions. Organic Zn sources are often more soluble in the rumen than inorganic sources (Spears, 2003), whereas hydroxy-TM (HTM) sources may be less soluble (Spears et al., 2004). IntelliBond C (basic copper chloride, Micronutrients Inc., Indianapolis, IN), IntelliBond M (manganese hydroxychloride; Micronutrients Inc.), and IntelliBond Z (zinc hydroxychloride; Micronutrients Inc.) are $\mathrm{Cu}, \mathrm{Mn}$, and $\mathrm{Zn}$ metal hydroxy sources, respectively, that should be less soluble in the rumen. It is anticipated that these sources will solubilize at a lesser $\mathrm{pH}$, as found in the abomasum and early small intestine, where absorption occurs. Lesser ruminal solubility of these sources may prevent decreased DM digestibility from TM supplementation, while still remaining available to the animal for absorption later in the intestine. The objective of this experiment was to compare the effect of sulfate TM (STM) and HTM sources at different inclusions on DM disappearance, NDF disappearance, and ruminal and simulated abomasal solubilities of $\mathrm{Cu}, \mathrm{Mn}$, and $\mathrm{Zn}$ in cattle fed corn silage-based diets formulated for a lactating dairy cow.

\section{MATERIALS AND METHODS}

\section{Experimental Design}

Five ruminally cannulated steers $(767 \pm 82 \mathrm{~kg})$ were used in a $5 \times 5$ Latin square design. Steers were individually fed a corn silage-based diet twice daily at 0700 and $1500 \mathrm{~h}$, formulated to meet the needs of a lactating dairy cow (milk yield $=36 \mathrm{~kg} / \mathrm{d}$ ), and allowed to consume water and feed on an ad libitum basis, for approximately $5 \%$ orts (Table 1 ). The 5 dietary treatments were as follows: control: no supplemental $\mathrm{Cu}$, $\mathrm{Mn}$, or $\mathrm{Zn}$, analyzed to contain $7.4 \mathrm{mg}$ of $\mathrm{Cu}, 30.8 \mathrm{mg}$ of $\mathrm{Mn}$, and $32.1 \mathrm{mg}$ of $\mathrm{Zn}$ per kilogram of diet DM (CON); low sulfate: $5 \mathrm{mg}$ of $\mathrm{Cu} / \mathrm{kg}$ of DM supplemented from $\mathrm{CuSO}_{4}, 15 \mathrm{mg}$ of $\mathrm{Mn} / \mathrm{kg}$ of $\mathrm{DM}$ from $\mathrm{MnSO}_{4}$, and $30 \mathrm{mg}$ of $\mathrm{Zn} / \mathrm{kg}$ of $\mathrm{DM}$ from $\mathrm{ZnSO}_{4}$ (LSTM); low HTM: $5 \mathrm{mg}$ of $\mathrm{Cu} / \mathrm{kg}$ of DM supplemented from basic copper chloride (IntelliBond $\mathrm{C}$ ), $15 \mathrm{mg}$ of $\mathrm{Mn} / \mathrm{kg}$ of DM from manganese hydroxychloride (IntelliBond M), and $30 \mathrm{mg}$ of $\mathrm{Zn} / \mathrm{kg}$ of DM from zinc hydroxychloride (IntelliBond Z; LHTM); high sulfate: $25 \mathrm{mg}$ of $\mathrm{Cu} /$ $\mathrm{kg}$ of DM supplemented from $\mathrm{CuSO}_{4}, 60 \mathrm{mg}$ of $\mathrm{Mn} /$ $\mathrm{kg}$ of $\mathrm{DM}$ from $\mathrm{MnSO}_{4}$, and $120 \mathrm{mg}$ of $\mathrm{Zn} / \mathrm{kg}$ of $\mathrm{DM}$ from $\mathrm{ZnSO}_{4}$ (HSTM); and high HTM: $25 \mathrm{mg}$ of $\mathrm{Cu} /$ $\mathrm{kg}$ of DM supplemented from basic copper chloride, 60 $\mathrm{mg}$ of $\mathrm{Mn} / \mathrm{kg}$ of DM from manganese hydroxychloride,
Table 1. Diet composition

\begin{tabular}{lc}
\hline Item & $\begin{array}{c}\% \text { of } \\
\text { diet DM }\end{array}$ \\
\hline Ingredient & \\
Corn silage & 41.0 \\
Grass hay & 19.0 \\
Soybean meal & 14.0 \\
Dried distillers grains with solubles & 15.0 \\
Dry-rolled corn & 8.5 \\
Limestone & 1.60 \\
Vitamin A premix & 1 \\
Salt & 0.15 \\
Trace mineral premix & \\
Treatment premix & \\
Calculated composition $_{\text {CP }^{4}}$ & 0.70 \\
NDF $^{4}$ & 0.05 \\
$\mathrm{~S}^{5}$ & 0.03 \\
\hline
\end{tabular}

${ }^{1}$ Vitamin A premix contained 4,400,000 IU of vitamin A per kilogram. ${ }^{2}$ Provided the following per kilogram of diet for all treatments: 0.11 $\mathrm{mg}$ of $\mathrm{Co}\left(\mathrm{CoCO}_{3}\right), 0.53 \mathrm{mg}$ of $\mathrm{I}\left[\mathrm{Ca}\left(\mathrm{IO}_{3}\right)_{2}\right], 0.3 \mathrm{mg}$ of $\mathrm{Se}\left(\mathrm{Na}_{2} \mathrm{SeO}_{3}\right)$.

${ }^{3}$ Provided the following per kilogram of diet for individual treatments: control: no supplemental $\mathrm{Cu}, \mathrm{Mn}$, or $\mathrm{Zn}$; low sulfate: $5 \mathrm{mg}$ of $\mathrm{Cu}$ $\left(\mathrm{CuSO}_{4}\right), 15 \mathrm{mg}$ of $\mathrm{Mn}\left(\mathrm{MnSO}_{4}\right)$, and $30 \mathrm{mg}$ of $\mathrm{Zn}\left(\mathrm{ZnSO}_{4}\right)$; low hydroxy trace mineral: $5 \mathrm{mg}$ of $\mathrm{Cu}$ (basic $\mathrm{Cu}$ chloride), $15 \mathrm{mg}$ of $\mathrm{Mn}$ (Mn hydroxychloride), and $30 \mathrm{mg}$ of $\mathrm{Zn}$ (Zn hydroxychloride); high sulfate: $25 \mathrm{mg}$ of $\mathrm{Cu}\left(\mathrm{CuSO}_{4}\right), 60 \mathrm{mg}$ of $\mathrm{Mn}\left(\mathrm{MnSO}_{4}\right)$, and $120 \mathrm{mg}$ of $\mathrm{Zn}\left(\mathrm{ZnSO}_{4}\right)$; and high hydroxy trace mineral: $25 \mathrm{mg}$ of $\mathrm{Cu}$ (basic $\mathrm{Cu}$ chloride), $60 \mathrm{mg}$ of $\mathrm{Mn}$ (Mn hydroxychloride), and $120 \mathrm{mg}$ of $\mathrm{Zn}$ ( $\mathrm{Zn}$ hydroxychloride).

${ }^{4}$ Calculated based on individual ingredient analysis from Dairyland laboratories (Arcadia, WI).

${ }^{5}$ Calculated based on ingredient values from NRC (2000), except for dried distillers grains with solubles, which was analyzed for $\mathrm{S}$ by Dairyland laboratories.

and $120 \mathrm{mg}$ of $\mathrm{Zn} / \mathrm{kg}$ of $\mathrm{DM}$ from zinc hydroxychloride (HHTM). Steers were adapted to a common diet, similar to the final diet, for $21 \mathrm{~d}$ before the beginning of the first period. Each 12-d period consisted of $10 \mathrm{~d}$ of diet adaptation, and in situ Dacron forage bags were inserted before feeding at $0600 \mathrm{~h}$ on d 11 .

Dry matter disappearance was measured using preweighed in situ forage bags $(10 \times 20 \mathrm{~cm}, 50-\mu \mathrm{m}$ porosity, Ankom Technology Corp., Macedon, NY). A TMR sample from the CON treatment (CON TMR was used as the substrate for all bags) was dried and ground through a 2-mm screen in a Wiley mill (Thomas Scientific, Swedesboro, NJ). A total of $4 \mathrm{~g}$ of CON TMR was added to each bag, and the bags were heat sealed. For each time point 6 total bags were used, 2 blank bags (not containing TMR) and 4 bags containing TMR. All bags (a total of 24 per steer) were added at $0 \mathrm{~h}$, and 6 bags were removed at each of 4 time points, after 6,12 , 24 , and $36 \mathrm{~h}$ of incubation. Once removed, bags were immediately immersed in ice water to cease fermentation and then transported to the laboratory on ice and frozen at $-20^{\circ} \mathrm{C}$. After bags were removed at $36 \mathrm{~h}$ after insertion, ruminal contents were sampled via a suction 
strainer, and subsamples were placed in $50-\mathrm{mL}$ conical tubes and immersed in ice water until being frozen at $-20^{\circ} \mathrm{C}$. All bags for each period were hand washed together with 15 changes of water until rinse water from the bags was clear. The final 2 washes were completed with deionized water. Bags were dried for $48 \mathrm{~h}$ at $70^{\circ} \mathrm{C}$ in a convection oven and weighed to determine DM disappearance. The percentage of DM disappearance at each time point was calculated as follows:

Percent DM disappearance at time $t=$

$$
\left[1-\left(X_{t} / A\right)\right] \times 100
$$

where $X=\mathrm{DM}$ remaining at time $t$, and $A=$ initial DM content before incubation.

Eight grams of whole rumen-fluid samples were subsampled in duplicate per steer per period and were subjected to ultracentrifugation at 28,000 $\times g$ for $30 \mathrm{~min}$ at $4^{\circ} \mathrm{C}$, and the supernatant was removed and considered the ruminally soluble fraction. To simulate abomasal conditions, rumen-fluid pellets remaining from the ultracentrifugation step were resuspended with $3 \mathrm{~mL}$ of supernatant, using methods similar to those previously reported (Ward and Spears, 1993). Samples were rinsed with $2 \mathrm{~mL}$ of $0.1 \mathrm{M} \mathrm{HCl}$ into a $15-\mathrm{mL}$ conical tube, and $450 \mu \mathrm{L}$ of a $1 \mathrm{M} \mathrm{HCl}$ and pepsin solution (0.6 mg of pep$\sin / \mathrm{mL}$, Fisher Scientific, Fair Lawn, NJ) was added. Samples were adjusted to a $\mathrm{pH}$ of approximately 2.5 using $1 \mathrm{M} \mathrm{HCl}$. Samples were incubated in an oscillating water bath $\left(39^{\circ} \mathrm{C}\right)$ for $1 \mathrm{~h}$. Samples were then placed in an ice bath for $15 \mathrm{~min}$, followed by centrifugation for 30 min at $1,000 \times g$ at $4^{\circ} \mathrm{C}$. The supernatant, containing the acid-soluble fraction, was removed and considered the simulated abomasal-soluble (acid-soluble) fraction.

Substrate from 2 in situ forage bags from each steer per period per time point were used for NDF analysis, and each bag was analyzed in duplicate. Material left in the bags was carefully removed and subsampled, and $0.25 \mathrm{~g}$ was placed in an Ankom fiber analyzer bag (F57 fiber filter bags, Ankom Technology Corp.) and heat sealed. Total NDF concentration was determined using an Ankom ${ }^{200}$ Fiber Analyzer (Ankom Technology Corp.), using the methods of VanSoest et al. (1991). Alpha-amylase was used during analysis. The percentage of NDF disappearance at each time point was calculated as follows:

Percent NDF disappearance at time $t=$

$$
\left[1-\left(Y_{t} / B\right)\right] \times 100
$$

where $Y=$ NDF remaining at time $t$, and $B=$ initial NDF content before incubation.
Total-mixed-ration samples were taken daily, dried in a forced-air oven at $70^{\circ} \mathrm{C}$ for $48 \mathrm{~h}$ for $\mathrm{DM}$ determination, ground through a $2-\mathrm{mm}$ screen in a Wiley Mill (Thomas Scientific), and composited by period for TM analysis. Feed refusals were weighed and sampled on the last $2 \mathrm{~d}$ of each experimental period, and samples were dried, ground, and composited in preparation for TM analysis. Total analyzed diet TM, DMI, and residual feed TM content were used to calculate total daily TM consumption.

All samples for TM analysis were digested using TMgrade nitric acid before TM analysis (CEMS MARSXpress, Matthews, NC) as described by Richter et al. (2012). Trace mineral analysis was completed using inductively coupled optic emission spectroscopy as described by Pogge and Hansen (2013).

\section{Statistical Analyses}

Data were analyzed as a $5 \times 5$ Latin square using the MIXED procedure of SAS (SAS Institute Inc., Cary, NC). The model included the fixed effects of dietary treatment, period, and steer. In the case of DM and NDF disappearance, hour was the repeated effect, and the subject for the repeated statement was steer nested within dietary treatment. Four a priori single-degreeof-freedom contrasts were developed: CON versus TM, comparing the CON treatment to TM-supplemented treatments; HTM versus STM, comparing HTM-supplemented treatments to STM treatments; CON versus STM, comparing the CON treatment to supplemental STM treatments; and CON versus HTM, comparing the CON treatment to supplemental HTM treatments. Data were checked for normalcy and homogeneity of variance. Outliers were determined using Cook's D statistic and if Cook's D >0.5, would have been removed, but no outliers were identified in this study. Data reported are least-squared means \pm standard error of the mean. Significance was declared at $P \leq 0.05$, and tendencies were declared from $P=0.06$ to 0.10 .

\section{RESULTS}

Dry matter intake did not differ due to treatment $(P \geq 0.15$; Table 2$)$. Analyzed dietary TM concentrations were slightly less than formulated, which may be due to sampling errors or other difficulties associated with adequate sampling of mineral supplements; however, STM and HTM did not differ $(P>0.30)$ for $\mathrm{Cu}$, $\mathrm{Mn}$, or Zn diet TMR content or daily TM intakes. As expected, because of experimental design, CON TM concentrations were lesser than supplemental TM treatments $(P<0.0001)$, and low supplemental TM treatments (LSTM and LHTM) had numerically lesser TM 
Table 2. Dry matter intake, dietary trace mineral (TM) concentrations, and daily TM intakes of cattle consuming diets with no supplemental TM, or sulfate-TM (STM) or hydroxy-TM (HTM) sources

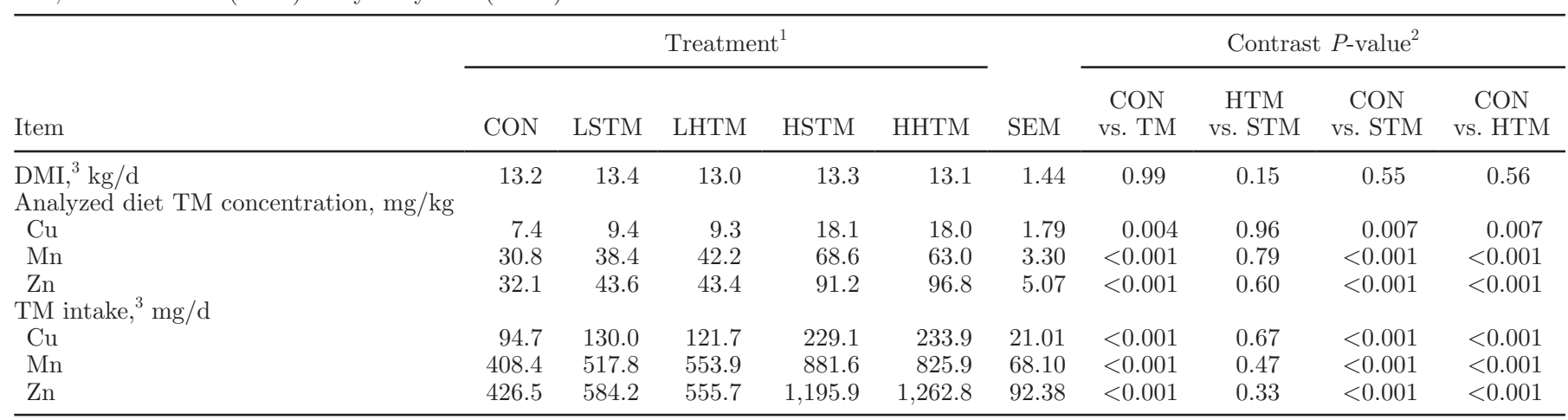

${ }^{1}$ Dietary treatments: control $=$ no supplemental $\mathrm{Cu}, \mathrm{Mn}$, or $\mathrm{Zn}(\mathrm{CON})$; low sulfate $=5 \mathrm{mg}$ of $\mathrm{Cu} / \mathrm{kg}$ of $\mathrm{DM}_{\text {from } \mathrm{CuSO}}, 15 \mathrm{mg}$ of $\mathrm{Mn} / \mathrm{kg}$ of $\mathrm{DM}$ from $\mathrm{MnSO}_{4}$, and $30 \mathrm{mg}$ of $\mathrm{Zn} / \mathrm{kg}$ of DM from $\mathrm{ZnSO}_{4}$ (LSTM); low HTM = $5 \mathrm{mg}$ of $\mathrm{Cu} / \mathrm{kg}$ of DM from basic copper chloride, $15 \mathrm{mg}$ of $\mathrm{Mn} / \mathrm{kg}$ of DM from manganese hydroxychloride, and $30 \mathrm{mg}$ of $\mathrm{Zn} / \mathrm{kg}$ of DM from zinc hydroxychloride (LHTM); high sulfate $=25 \mathrm{mg}$ of Cu/ $\mathrm{kg}$ of DM from $\mathrm{CuSO}_{4}, 60 \mathrm{mg}$ of $\mathrm{Mn} / \mathrm{kg}$ of $\mathrm{DM}$ from $\mathrm{MnSO}_{4}$, and $120 \mathrm{mg}$ of Zn/kg of DM from ZnSO ${ }_{4}$ (HSTM); and high HTM = 25 mg of $\mathrm{Cu} / \mathrm{kg}$ of $\mathrm{DM}$ from basic copper chloride, $60 \mathrm{mg}$ of $\mathrm{Mn} / \mathrm{kg}$ of DM from manganese hydroxychloride, and $120 \mathrm{mg}$ of Zn/kg of DM from zinc hydroxychloride (HHTM).

${ }^{2}$ Contrasts: CON vs. TM = CON versus LSTM, LHTM, HSTM, and HHTM; HTM vs. STM = LHTM and HHTM versus LSTM and HSTM; CON vs. $\mathrm{STM}=\mathrm{CON}$ versus LSTM and HSTM; and CON vs. HTM $=$ CON versus LHTM and HHTM.

${ }^{3}$ Based on repeated measures; day: $P \geq 0.30$; treatment $\times$ day: $P \geq 0.94$.

concentrations than high supplemental TM treatments (HSTM and HHTM), although this was not statistically tested based on the contrasts used in this study.

Trace mineral supplementation tended to have a negative effect on DM disappearance as assessed by repeated measures analysis $(P=0.06$; Table 3$)$. Steers fed the CON treatment had greater ruminal DM disappearance than STM-supplemented treatments $(P=$ $0.03)$, whereas CON and HTM-supplemented treat- ments did not differ $(P=0.18)$. However, HTM- and STM-supplemented treatments did not differ $(P=$ $0.32)$. Trace mineral source or concentration had no effect on NDF disappearance $(P \geq 0.20)$.

Ruminal $\mathrm{pH}$ measured at $36 \mathrm{~h}$ after insertion of bags was unaffected by dietary treatment $(P \geq 0.64)$ and averaged $6.4 \pm 0.30$ across treatments.

Whole rumen-fluid concentrations of both $\mathrm{Cu}$ and $\mathrm{Zn}$ were not different between HTM and STM sources $(P$

Table 3. Effect of trace mineral (TM) source and concentration on DM and NDF disappearance in cattle consuming diets with no supplemental TM, or sulfate TM (STM) or hydroxy-TM (HTM) sources

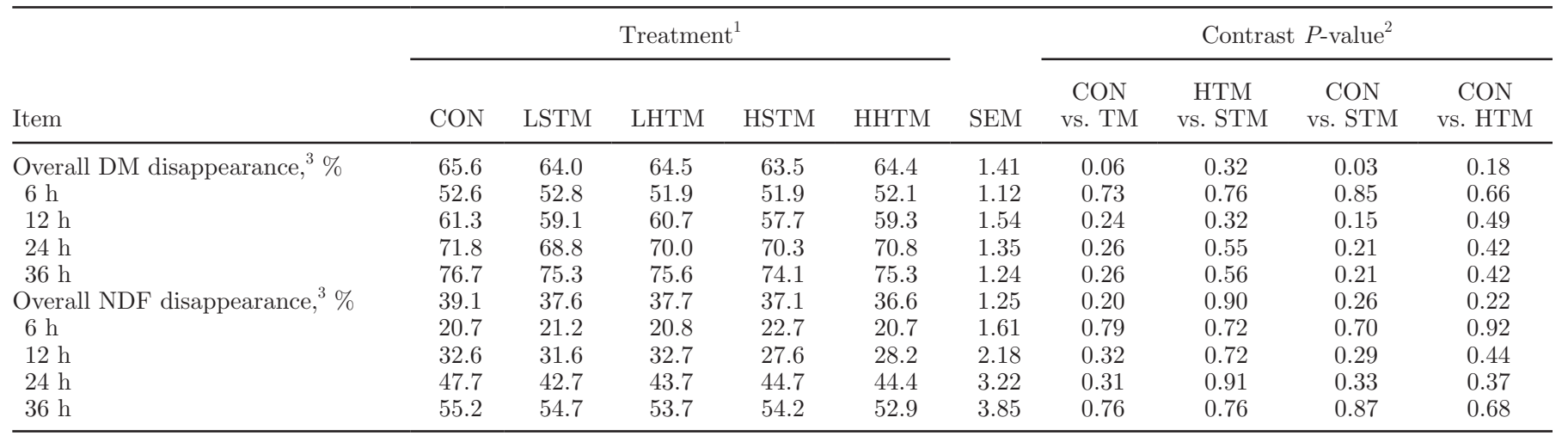

${ }^{1}$ Dietary treatments: control $=$ no supplemental $\mathrm{Cu}, \mathrm{Mn}$, or $\mathrm{Zn}(\mathrm{CON})$; low sulfate $=5 \mathrm{mg}$ of $\mathrm{Cu} / \mathrm{kg}$ of $\mathrm{DM}$ from $\mathrm{CuSO}_{4}, 15 \mathrm{mg}$ of $\mathrm{Mn} / \mathrm{kg}$ of $\mathrm{DM}$ from $\mathrm{MnSO}_{4}$, and $30 \mathrm{mg}$ of $\mathrm{Zn} / \mathrm{kg}$ of DM from $\mathrm{ZnSO}_{4}$ (LSTM); low HTM = $5 \mathrm{mg}$ of Cu/kg of DM from basic copper chloride, $15 \mathrm{mg}$ of $\mathrm{Mn} / \mathrm{kg}$ of DM from manganese hydroxychloride, and $30 \mathrm{mg}$ of $\mathrm{Zn} / \mathrm{kg}$ of DM from zinc hydroxychloride (LHTM); high sulfate $=25 \mathrm{mg}$ of Cu/ $\mathrm{kg}$ of $\mathrm{DM}$ from $\mathrm{CuSO}_{4}, 60 \mathrm{mg}$ of $\mathrm{Mn} / \mathrm{kg}$ of $\mathrm{DM}$ from $\mathrm{MnSO}_{4}$, and $120 \mathrm{mg}$ of $\mathrm{Zn} / \mathrm{kg}$ of DM from ZnSO $(\mathrm{HSTM})$; and high HTM = 25 mg of $\mathrm{Cu} / \mathrm{kg}$ of DM from basic copper chloride, $60 \mathrm{mg}$ of $\mathrm{Mn} / \mathrm{kg}$ of DM from manganese hydroxychloride, and $120 \mathrm{mg}$ of $\mathrm{Zn} / \mathrm{kg}$ of DM from zinc hydroxychloride (HHTM).

${ }^{2}$ Contrasts: CON vs. TM = CON versus LSTM, LHTM, HSTM, and HHTM; HTM vs. STM = LHTM and HHTM versus LSTM and HSTM; CON vs. STM $=$ CON versus LSTM and HSTM; and CON vs. HTM $=$ CON versus LHTM and HHTM.

${ }^{3}$ Based on repeated measures; hour: $P<0.0001$; treatment $\times$ hour: $P \geq 0.96$. 
$\leq 0.21$; Table 4 ), and supplemental TM treatments had greater concentrations of $\mathrm{Cu}, \mathrm{Mn}$, and $\mathrm{Zn}(P<0.0001)$ compared with CON. The solubility of TM from each dietary treatment was evaluated from rumen-fluid samples taken at $36 \mathrm{~h}$ after bag insertion, through ultracentrifugation. As expected, the concentration of ruminally soluble $\mathrm{Cu}$ from CON steers was lesser than that from TM-supplemented treatments $(P<0.0001$; Table 4$)$ and STM $(P<0.0001)$ and HTM treatments $(P=0.01)$. Ruminally soluble $\mathrm{Cu}$ was lesser in HTM treatments than in STM treatments $(P<0.0001)$. Similarly, CON had less ruminally soluble Mn than TM-supplemented treatments, regardless of TM source $(P \geq 0.0005)$. Hydroxy-TM-supplemented treatments had lesser ruminally soluble Mn than did STM $(P<$ 0.0001). Ruminally soluble $\mathrm{Zn}$ concentrations were less in CON than in TM-supplemented treatments $(P$ $=0.02)$. Hydroxy-TM-supplemented treatments had greater ruminally soluble Zn than did STM $(P=0.01)$, mainly driven by a greater concentration in the HHTM treatment, which also drove the differences between CON and HTM treatments $(P=0.003)$. Ruminally soluble Zn did not differ between CON and STM $(P=$ 0.25). Ruminally soluble TM as a percentage of whole rumen-fluid TM concentration was determined. The CON treatment and STM did not differ for $\mathrm{Cu}(P=$ $0.68)$, but HTM were less soluble as a proportion of total $\mathrm{Cu}$ in the rumen fluid $(P=0.006)$. Ruminally soluble $\mathrm{Mn}$ as a percentage of whole rumen-fluid $\mathrm{Mn}$ tended to be lesser in CON than in STM $(P=0.06)$ but was not different from HTM $(P=0.33)$, and HTM was not different from STM $(P=0.21)$. The CON was more soluble as a proportion of whole ruminal-fluid $\mathrm{Zn}$ than supplemental-TM treatments $(P<0.0001)$, and HTM were more soluble than STM $(P=0.04)$ relative to whole rumen-fluid $\mathrm{Zn}$ content.

Rumen fluid samples were subjected to digestion in simulated in vitro abomasal conditions, and the acidsoluble TM concentrations were determined. Copper concentrations after simulated abomasal digestion were less than ruminally soluble $\mathrm{Cu}$ concentrations (Table 4 ); however, no treatment differences were noted ( $P$ $\geq 0.43$ ). Acid-soluble $\mathrm{Mn}$ concentrations were slightly numerically greater than ruminally soluble Mn concentrations. The CON treatment had lesser acid-soluble Mn concentrations than did TM-supplemented treatments, regardless of source $(P<0.0001)$, and HTM remained less soluble then STM $(P=0.007)$. Acid-

Table 4. Effect of trace mineral (TM) concentration and source on ruminal-fluid TM concentrations and ruminal and simulated abomasal solubilities in cattle consuming diets with no supplemental TM, or sulfate-TM (STM) or hydroxy-TM (HTM) sources

\begin{tabular}{|c|c|c|c|c|c|c|c|c|c|c|}
\hline Item & \multicolumn{5}{|c|}{ Treatment $^{1}$} & SEM & \multicolumn{4}{|c|}{ Contrast $P$-value ${ }^{2}$} \\
\hline $\mathrm{Cu}$ & 0.70 & 1.13 & 1.06 & 2.23 & 1.99 & 0.147 & $<0.001$ & 0.24 & $<0.001$ & $<0.001$ \\
\hline $\mathrm{Mn}$ & 2.93 & 4.53 & 4.24 & 8.31 & 7.15 & 0.457 & $<0.001$ & 0.02 & $<0.001$ & $<0.001$ \\
\hline $\mathrm{Zn}$ & 2.95 & 5.65 & 5.00 & 10.00 & 8.99 & 0.798 & $<0.001$ & 0.21 & $<0.001$ & $<0.001$ \\
\hline $\mathrm{Zn}$ & 0.52 & 0.57 & 0.67 & 0.68 & 1.02 & 0.072 & 0.02 & 0.01 & 0.25 & 0.003 \\
\hline \multicolumn{11}{|c|}{ Rumen soluble, ${ }^{4} \%$ of whole rumen fluid } \\
\hline $\mathrm{Cu}$ & 16.1 & 17.1 & 14.9 & 14.0 & 9.1 & 1.40 & 0.07 & 0.005 & 0.68 & 0.01 \\
\hline $\mathrm{Mn}$ & 52.8 & 61.8 & 49.8 & 64.5 & 65.9 & 4.81 & 0.12 & 0.21 & 0.06 & 0.33 \\
\hline $\mathrm{Zn}$ & 18.7 & 12.0 & 13.9 & 7.2 & 11.4 & 1.45 & 0.003 & 0.04 & $<0.001$ & 0.003 \\
\hline \multicolumn{11}{|c|}{ Acid soluble, ${ }^{5} \mathrm{mg} / \mathrm{L}$} \\
\hline
\end{tabular}

${ }^{1}$ Dietary treatments: control $=$ no supplemental $\mathrm{Cu}, \mathrm{Mn}$, or $\mathrm{Zn}(\mathrm{CON})$; low sulfate $=5 \mathrm{mg}$ of $\mathrm{Cu} / \mathrm{kg}$ of $\mathrm{DM}$ from CuSO${ }_{4}, 15 \mathrm{mg}$ of $\mathrm{Mn} / \mathrm{kg}$ of DM from $\mathrm{MnSO}_{4}$, and $30 \mathrm{mg}$ of $\mathrm{Zn} / \mathrm{kg}$ of DM from $\mathrm{ZnSO}_{4}$ (LSTM); low HTM $=5 \mathrm{mg}$ of $\mathrm{Cu} / \mathrm{kg}$ of DM from basic copper chloride, 15 mg of $\mathrm{Mn} / \mathrm{kg}$ of DM from manganese hydroxychloride, and $30 \mathrm{mg}$ of $\mathrm{Zn} / \mathrm{kg}$ of DM from zinc hydroxychloride (LHTM); high sulfate $=25 \mathrm{mg}$ of Cu/ $\mathrm{kg}$ of DM from $\mathrm{CuSO}_{4}, 60 \mathrm{mg}$ of $\mathrm{Mn} / \mathrm{kg}$ of $\mathrm{DM}$ from $\mathrm{MnSO}_{4}$, and $120 \mathrm{mg}$ of Zn/kg of DM from ZnSO 4 (HSTM); and high HTM = $25 \mathrm{mg}$ of $\mathrm{Cu} / \mathrm{kg}$ of DM from basic copper chloride, $60 \mathrm{mg}$ of Mn/ $\mathrm{kg}$ of DM from manganese hydroxychloride, and $120 \mathrm{mg}$ of Zn/ $\mathrm{kg}$ of DM from zinc hydroxychloride (HHTM).

${ }^{2}$ Contrasts: CON vs. TM = CON versus LSTM, LHTM, HSTM, and HHTM; HTM vs. STM = LHTM and HHTM versus LSTM and HSTM; CON vs. STM $=$ CON versus LSTM and HSTM; and CON vs. HTM = CON versus LHTM and HHTM.

${ }^{3}$ Rumen-soluble mineral was the mineral present in the supernatant fraction after whole rumen-fluid ultracentrifugation.

${ }^{4}$ Rumen-soluble mineral as a percentage of whole ruminal mineral was determined by calculating the total amount of soluble mineral in each sample after ultracentrifugation and dividing that number by the calculated amount of mineral in each sample before ultracentrifugation.

${ }^{5}$ Acid-soluble mineral was the mineral present in the supernatant fraction after ruminal fluid was subjected to acid digestion to simulate abomasal conditions. 
soluble $\mathrm{Zn}$ concentrations were lesser in CON than in TM-supplemented treatments $(P \leq 0.0003)$. The HTM treatments had greater acid-soluble $\mathrm{Zn}$ than sulfate treatments $(P=0.03)$, mainly driven by the difference between HSTM and HHTM treatments.

\section{DISCUSSION}

Trace minerals are essential for proper health and growth of animals (Suttle, 2010) and are often supplemented to cattle, but interactions with other dietary factors, including sulfur and molybdenum, can prevent absorption by forming insoluble complexes (Spears, 2003). Trace minerals such as basic copper chloride that do not become soluble in the ruminal environment, but instead solubilize at a lesser $\mathrm{pH}$ (Spears et al., 2004), such as that found in the abomasum, may aid in the prevention of the formation of these complexes (Spears, 2003). Although a survey of common TM-supplementation practices in the dairy industry has not been completed, they are likely to be similar to practices in the beef industry, where TM are often supplemented at concentrations greater than NRC (2000) recommendations (Vasconcelos and Galyean, 2007). Although additional TM may be required in some situations, the effects on ruminal metabolism are not well understood.

In the present study overall DM disappearance was negatively affected by TM supplementation when compared with cattle not receiving supplemental $\mathrm{Cu}, \mathrm{Mn}$, or $\mathrm{Zn}$; however, individual comparisons revealed that DM disappearance was decreased by the supplementation of STM but not HTM. It appears that STM negatively affect DM disappearance, whereas HTM do not significantly interfere with DM disappearance. Previous research has demonstrated that supplemental $\mathrm{ZnCl}_{2}$ tends to decrease in situ DM digestibility but only in excessive concentrations (470 $\mathrm{mg}$ of $\mathrm{Zn} / \mathrm{kg}$ of DM; Arelovich et al., 2000), and further research concluded that $430 \mathrm{mg}$ of $\mathrm{Zn} / \mathrm{kg}$ of diet $\mathrm{DM}$ from $\mathrm{ZnCl}_{2}$ did not affect alfalfa-hay or barley-grain degradability (Arelovich et al., 2008). Furthermore, supplementing $12.22 \mathrm{mg}$ of $\mathrm{Cu} / \mathrm{kg}$ of diet $\mathrm{DM}$ from $\mathrm{CuSO}_{4}$ to heifers actually improved DM disappearance rate and digestibility of alfalfa hay and corn cobs (Lopez-Guisa and Satter, 1992). However, it appears that when $\mathrm{Cu}, \mathrm{Mn}$, and $\mathrm{Zn}$ are fed together from sulfate sources, the extent of DM disappearance may decline. In situations where DM digestion and subsequent passage rate are especially critical, such as in a high-producing dairy cow, supplementation of TM in the metal-hydroxy form may prevent negative influences of high concentrations of TM on feed intake and digestibility of diets.
Previous research suggests that differences in DM disappearance due to TM supplementation may be caused by a decrease in fiber digestion. Bonhomme et al. (1979) found that $10 \mu \mathrm{g}$ of $\mathrm{Zn} / \mathrm{mL}$ decreased in vitro cellulose digestion (calculated by the authors to be approximately $400 \mathrm{mg}$ of $\mathrm{Zn} / \mathrm{kg}$ of diet $\mathrm{DM}$ ), but others have found greater concentrations are required for an inhibitory effect ( $50 \mu \mathrm{g}$ of $\mathrm{Zn} / \mathrm{mL}$; Eryavuz and Dehority, 2009). The authors suggested that excessive Zn might inhibit bacterial attachment to cellulose by binding to the surface of bacteria, decreasing cellulose hydrolysis (Eryavuz and Dehority, 2009). However, no effect of supplemental TM on NDF digestion was apparent in the present study, suggesting that digestion of other nutrients may be affected by TM supplementation, although the effect on cellulose specifically was undetermined. Arthington (2005) reported that $\mathrm{Cu}-$ oxide wire boluses placed inside the rumen decreased $\mathrm{NDF}$ and $\mathrm{CP}$ digestibility but not OM digestibility, identifying differences in $\mathrm{CP}$ as a potential cause of decreased DM digestion. Additionally, supplemental Zn may decrease bacterial protease activity, decreasing dietary protein digestion (Eryavuz and Dehority, 2009). However, CP disappearance was not measured in this study.

Based on the chemistry of the HTM sources, we hypothesized that $\mathrm{Cu}, \mathrm{Mn}$, and $\mathrm{Zn}$ from these sources would be less soluble than STM in the higher $\mathrm{pH}$ of the rumen, and this was found to be true for $\mathrm{Cu}$ and Mn but not Zn. Spears et al. (2004) found that basic copper chloride was insoluble in water, but after incubation in $0.1 \% \mathrm{HCl}$, basic copper chloride was much more soluble. Similarly, Spears (2003) suggested that $\mathrm{Cu}$ from basic copper chloride is less soluble at the $\mathrm{pH}$ found in the rumen, although other research in cattle is lacking. In this study, once exposed to conditions similar to those found in the abomasum, solubility did not differ among TM sources. These results indicate that $\mathrm{Cu}$ from HTM will be less soluble in the rumen and less available to form interactions with Mo, S, and fiber but will act similarly to STM in the abomasum. The samples analyzed in this study were frozen before ultracentrifugation and separation of the soluble and insoluble fraction. It is possible that freezing may influence the distribution of minerals, through potential lysing of cells and mineral release. However, all samples were treated in the same manner throughout the study, allowing for appropriate comparison within the study.

Acid-soluble $\mathrm{Cu}$ concentrations were less than ruminally soluble concentrations, regardless of treatment, which though unexpected, is similar to previous research (Ward and Spears, 1993). Those authors hypothesized that $\mathrm{Cu}$ could be bound to denatured microbial protein 
or present in another form that is insoluble in low $\mathrm{pH}$, such as CuS (Ward and Spears, 1993). Additionally as dietary protein increases, soluble $\mathrm{Cu}$ decreases in the abomasum (Ivan and Veira, 1981), and approximately $55 \%$ of $\mathrm{Cu}$ found in the abomasum of sheep is found associated with microbial matter, limiting solubility (Bremner, 1970). This may be relevant to the present study, because the diet was formulated for a lactating dairy cow and therefore had high dietary CP (17.5\% $\mathrm{CP})$.

Although others have reported that ruminally soluble Mn concentrations are lesser than those found in the abomasum (Bremner, 1970; Kabaija and Smith, 1988), concentrations appeared similar between acid and ruminally soluble Mn concentrations in the present study, although this was not tested statistically, with the contrasts used in this study. Ruminally soluble concentrations of Mn from HTM steers were lesser than STM, suggesting that HTM are less available in the rumen and increasing dietary $\mathrm{Mn}$ concentration increased acid-soluble Mn, and HTM remained less acid soluble than STM. This difference may be explained by the fact that whole ruminal-fluid Mn was numerically lesser in the HHTM than the HSTM, as there may have been less $\mathrm{Mn}$ in the whole rumen fluid available to become soluble under simulated abomasal conditions. Unlike $\mathrm{Cu}$, very little is known about how Mn may be affected under ruminal conditions, but it seems that $\mathrm{Mn}$ has similar solubility characteristics to $\mathrm{Cu}$ based on the results from this study and could prevent currently unknown ruminal interactions, and still remain available for absorption. Beef steers fed diets containing excessive $\mathrm{S}(0.68 \% \mathrm{~S})$ had negative $\mathrm{Mn}$ retention (Pogge et al., 2014), suggesting that sulfide may reduce Mn status, potentially through ruminal formation of an insoluble Mn-S complex.

Contrary to our hypothesis, ruminally soluble Zn concentrations were greater in HTM treatments, because of greater concentrations in the HHTM treatment. Others have observed similarly unexpected shifts in ruminally soluble Zn. Kennedy et al. (1993) demonstrated that a polysaccharide-bound $\mathrm{Zn}$ was initially very soluble in the rumen through $2 \mathrm{~h}$ after $\mathrm{Zn}$ dosing but was not different from $\mathrm{ZnO}$ from 3 to $8 \mathrm{~h}$ after dosing. Interestingly, from 3 to $8 \mathrm{~h}$ after $\mathrm{Zn}$ dosing, polysaccharide $\mathrm{Zn}$ was greater in the particle-associated fraction, suggesting that $\mathrm{Zn}$ from a soluble source may be released initially but may then become bound to particulate or microbial matter, potentially interfering with microbial digestion. In the present study if $\mathrm{ZnSO}_{4}$ was indeed more soluble than HTM Zn, then it may be quickly binding to fiber in the rumen and thus be captured in the nonsoluble fraction, which could explain the lesser ruminal-soluble Zn found in HSTM relative to HHTM.
However, because soluble $\mathrm{Zn}$ as a percentage of whole ruminal-Zn concentration was also greater in HTM, this may not be the case, and further work is necessary to clarify the availability of Zn from HTM sources in cattle diets. Zinc bound to particulate matter and preventing microbial attachment and digestion (Eryavuz and Dehority, 2009) may have caused the lesser DM disappearance due to STM sources. Acid-soluble Zn remained greater in the HTM sources relative to STM, driven mainly by the difference between HSTM and HHTM, suggesting that perhaps more $\mathrm{Zn}$ would be available to the absorptive enterocytes of the small intestine.

The rumen presents a unique challenge to the absorption of TM, because the formation of insoluble complexes can decrease the later availability of certain TM. Sulfide, generated from reduction of sulfate in the rumen (Drewnoski et al., 2014), can combine with dietary Mo to form thiomolybdates and complex with $\mathrm{Cu}$ and bind directly to $\mathrm{Cu}$ to form insoluble $\mathrm{Cu}$ sulfide (Suttle, 1991). Beef cattle fed diets containing excessive dietary $\mathrm{S}(0.68 \% \mathrm{~S})$ have lesser absorption and retention of $\mathrm{Cu}, \mathrm{Mn}$, and $\mathrm{Zn}$ (Pogge et al., 2014). However, $\mathrm{Cu}$ must be in a soluble form, and not bound to particulate matter, to be available for interaction with Mo and S (Suttle, 1991). This is an opportunity to use less ruminally soluble TM, especially in diets that contain high concentrations of $\mathrm{S}$ and Mo, which can be typical in both beef and dairy cattle diets, to prevent undesirable interactions and provide ruminants with $\mathrm{Cu}$ available for absorption. The HTM seem an ideal source, especially given the clear differences in ruminal solubility between sources found in this study. Differences in ruminal and abomasal solubility may not affect overall bioavailability of the TM source; however, this has not been investigated thoroughly.

Overall, DM disappearance was negatively affected by TM supplementation, but this trend was driven by the sulfate-bound TM, because HTM had no significant effect on DM disappearance. Disappearance of NDF did not differ by treatment, suggesting that TM supplementation may be affecting digestion of another nutrient such as starch or CP. Finally, both $\mathrm{Cu}$ and $\mathrm{Mn}$ from HTM sources appear to be relatively ruminally insoluble when compared with STM. Under simulated abomasal conditions, $\mathrm{Cu}$ HTM are equally as soluble as STM and may be able to prevent insoluble complex formation within the rumen and yet remain available for absorption in the small intestine. Manganese from HTM remained less acid soluble than STM. Overall, Zn from HTM was more soluble than STM under both ruminal and simulated abomasal conditions; however, further work is necessary to define the interaction between $\mathrm{Zn}$ and particulate matter within the rumen. 


\section{REFERENCES}

Arelovich, H. M., H. E. Laborde, M. I. Amela, M. B. Torrea, and M. F. Martinez. 2008. Effects of dietary addition of zinc and (or) monensin on performance, rumen fermentation and digesta kinetics in beef cattle. Span. J. Agric. Res. 6:362-372.

Arelovich, H. M., F. N. Owens, G. W. Horn, and J. A. Vizcarra. 2000. Effects of supplemental zinc and manganese on ruminal fermentation, forage intake, and digestion by cattle fed prairie hay and urea. J. Anim. Sci. 78:2972-2979.

Arthington, J. D. 2005. Effects of copper oxide bolus administration or high-level copper supplementation on forage utilization and copper status in beef cattle. J. Anim. Sci. 83:2894-2900.

Bonhomme, A., M. Durand, C. Dumay, and P. Beaumatin. 1979. Etude in vitro du comportement des populations microbiennes du rumen en presence de zinc sous forme de sulfate. Ann. Biol. Anim. Biochim. Biophys. 19:937-942.

Bremner, I. 1970. Zinc, copper, and manganese in the alimentary tract of sheep. Br. J. Nutr. 24:769-783.

Drewnoski, M. E., D. J. Pogge, and S. L. Hansen. 2014. High-sulfur in beef cattle diets: A review. J. Anim. Sci. 92:3763-3780. http:// dx.doi.org/10.2527/jas.2013-7242.

Engle, T. E., and J. W. Spears. 2000a. Effects of dietary copper concentration and source on performance and copper status of growing and finishing steers. J. Anim. Sci. 78:2446-2451.

Engle, T. E., and J. W. Spears. 2000b. Dietary copper effects on lipid metabolism, performance, and ruminal fermentation in finishing steers. J. Anim. Sci. 78:2452-2458.

Eryavuz, A., and B. A. Dehority. 2009. Effects of supplemental zinc concentration on cellulose digestion and cellulolytic and total bacterial numbers in vitro. Anim. Feed Sci. Technol. 151:175-183.

Hubbert, F., Jr., E. Cheng, and W. Burroughs. 1958. Mineral requirement of rumen microorganisms for cellulose digestion in vitro. J. Anim. Sci. 17:559-568.

Ivan, M., and D. M. Veira. 1981. Effect of dietary protein on the solubilities of manganese, copper, zinc, and iron in the rumen of abomasum of sheep. Can. J. Anim. Sci. 61:955-959.

Kabaija, E., and O. B. Smith. 1988. Trace element kinetics in the digestive tract of sheep fed diets with graded levels of dietary fibre. J. Anim. Physiol. Anim. Nutr. (Berl.) 59:218-224.

Kennedy, D. W., W. M. Craig, and L. L. Southern. 1993. Ruminal distribution of zinc in steers fed a polysaccharide-zinc complex or zinc oxide. J. Anim. Sci. 71:1281-1287.
Lopez-Guisa, J. M., and L. D. Satter. 1992. Effect of copper and cobalt addition on digestion and growth in heifers fed diets containing alfalfa silage or corn crop residues. J. Dairy Sci. 75:247-256.

Martinez, A., and D. C. Church. 1970. Effects of various mineral elements on in vivo rumen cellulose digestion. J. Anim. Sci. 31:982990.

NRC. 2000. Nutrient Requirements of Beef Cattle. Update of the 7th rev. ed. Natl. Acad. Press, Washington, DC.

Pogge, D. J., M. E. Drewnoski, and S. L. Hansen. 2014. High dietary sulfur decreases the retention of copper, manganese, and zinc in steers. J. Anim. Sci. 92:2182-2191.

Pogge, D. J., and S. L. Hansen. 2013. Supplemental vitamin C improves marbling in feedlot cattle consuming high sulfur diets. J. Anim. Sci. 91:4303-4314.

Richter, E. L., M. E. Drewnoski, and S. L. Hansen. 2012. Effects of increased dietary sulfur on beef steer mineral status, performance and meat fatty acid composition. J. Anim. Sci. 90:3945-3953.

Somers, M., and E. J. Underwood. 1969. Studies of zinc nutrition in sheep. II. The influence of zinc deficiency in ram lambs upon the digestibility of the dry matter and the utilization of the nitrogen and sulfur of the diet. Aust. J. Agric. Res. 20:899-903.

Spears, J. W. 2003. Trace mineral bioavailability in ruminants. J. Nutr. 133:1506S-1509S.

Spears, J. W., E. B. Kegley, and L. A. Mullis. 2004. Bioavailability of copper from tribasic copper chloride and copper sulfate in growing cattle. Anim. Feed Sci. Technol. 116:1-13.

Suttle, N. F. 1991. The interactions between copper, molybdenum, and sulphur in ruminant nutrition. Annu. Rev. Nutr. 11:121-140.

Suttle, N. F. 2010. Zinc. Pages 426-458 in The Mineral Nutrition of Livestock. 4th ed. CABI Publ., New York, NY.

Van Soest, P. J., J. B. Robertson, and B. A. Lewis. 1991. Methods for dietary fiber, neutral detergent fiber, and nonstarch polysaccharides in relation to animal nutrition. J. Dairy Sci. 74:3583-3597.

Vasconcelos, J. T., and M. L. Galyean. 2007. Nutritional recommendations of feedlot consulting nutritionists, The 2007 Texas Tech University survey. J. Anim. Sci. 85:2772-2781.

Ward, J. D., and J. W. Spears. 1993. Comparison of copper lysine and copper sulfate as copper sources for ruminants using in vitro methods. J. Dairy Sci. 76:2994-2998. 